\title{
A Perspective
}

\section{Guidepost to Wealth Creation: Value-Relevant Track Records}

\author{
Bartley J. Madden
}

\begin{abstract}
In creating wealth, the corporate sector is hampered by weaknesses in the corporate governance system and the accounting system. The analysis presented in this article supports recommendations that managements and boards: 1) provide value-relevant, long-term track records for the firm and its major business units, and 2) use these track records to explain how their key decisions are consistent with long-term value maximization. Potential benefits include: 1) expedited learning by managements and boards about connections between economic performance and shareholder value; 2) abandonment of quarterly earnings as a decision guide; 3) more productive dialogue among the board, management, and investors, leading to quicker and better decisions for maximizing shareholder value; and 4) more attention by accounting rule-makers to the experiences of primary users of accounting data in dealing with measurement problems critical to wealth creation, such as the handling of intangible assets. [D21, G38, L21]
\end{abstract}

In creating wealth, the corporate sector is hampered by weaknesses in two vital areas, the corporate governance system and the accounting system. Generally treated separately, both problem areas can be improved simultaneously by having management provide value-relevant, long-term track records to the investing public.

Criticism of corporate governance has focused on at least three issues. First, managements (with explicit or implicit board approval) operate with an extreme focus on at least meeting, and hopefully beating, quarterly earnings expectations. But this is to the detriment of long-term value creation (Rappaport, 2005). Second, boards fail to adequately tie management compensation to wealth creation (Bebchuk and Fried, 2004). Third, management dominance of the nominating process for board members denies the firms' common stock owners effective representation (Bebchuk, 2007).

Accounting rule-makers are struggling with ways to deal with the new business environment in which investments in intangible assets (expensed outlays for resources that contribute to cash flow over multiple future periods) are overtaking investments in booked tangible assets. As a consequence, today's transaction-based accounting system understates assets and distorts earnings, due to a mismatch between revenues and expenses. These accounting distortions are not only a major problem for individual firms, but also impact the usefulness of national income accounts (Corrado, Haltiwanger, and Sichel, 2005).

Bartley J. Madden is an independent researcher in Naperville, IL. His website is www.LearningWhatWorks.com.
The challenge is how best to transition to a value-relevant accounting system, one that better allows for intangibles, and thus better informs decision making for both management and investors. Better decisions lead to improved resource allocation and more wealth creation.

Both the corporate governance system and the accounting system have the ultimate objective of facilitating wealth creation. Consistent with that objective, this article argues for shareholders to demand that managements and boards: 1) provide value-relevant, long-term track records for the firm and its major business units, and 2) in the context of these track records, provide substantive explanations of why key corporate decisions are consistent with long-term value maximization (Charron, 2007).

The major sections that follow build upon the logical assumption that value maximization necessarily requires a valuation model with specified inputs (variables) to guide decision making. The sensible approach to implementation of a valuation model is to show track records as historical values of the variables which serve as the inputs to the selected valuation model.

The first section deals with the primary problem with the status quo situation. That is, for a great many firms, management's implicit valuation model centers on earnings per share growth and, in particular, on meeting or exceeding quarterly EPS expectations.

From a discounted cash flow perspective on valuation, selection of a valuation model primarily involves choosing from a menu of different approaches for estimating the firm's long-term net cash receipt stream, the main valuation driver. The differences among models amount 
to ways of packaging the firm's expected patterns over time (life-cycles) of economic returns, reinvestment rates, competitive fade, and cost of capital. The life-cycle model is particularly suitable for valuing firms from a DCF foundation and is used in this article, but clearly other consistent DCF approaches would also work.

The life-cycle track record for Eastman Kodak, 1950 to 2006, illustrates how accounting data can be translated into an easy-to-understand display of long-term valuation drivers. Building charts of track records for a firm and its major business units involves a critical tradeoff between accuracy and simplicity (as well as lower computational costs). The valuation models and related track records in widespread commercial use (e.g., CFROI and EVA) and other hybrids could be evaluated by corporations based on their accuracy/simplicity tradeoffs and a model's overall usefulness to a firm (Trammell, 2004).

The most critical track record variable is the estimate of economic returns. The task is to make accounting adjustments to better reflect business economics. Oftentimes this involves thorny issues with intangibles.

A commitment to value-relevant track records by publicly held corporations would force corporate executives to become meaningfully engaged with the value-relevant issues in improving the 500-year-old, transaction-based, accounting system. Is it not rather important to have those making pivotal decisions for creating wealth, those with the most detailed business knowledge, be actively involved in developing useful ways to handle accounting/performance measurement issues and to communicate that to investors?

The proposal for displaying track records and explaining key business unit decisions (most appropriately as a part of the annual report) would create a high-priority need for managements to experiment with and continually improve the handling of tough measurement issues like intangibles. This hands-on experience would, over time, establish firms' preferences for accuracy versus simplicity, and for objectivity versus relevance. This is the heart of the challenge of transitioning to an improved accounting system.

The concluding section summarizes the potential benefits to wealth creation if these ideas are implemented.

\section{Theory versus Practice}

As for valuation expertise, managements and boards of directors are not as highly motivated to develop practical and insightful valuation models as are portfolio managers, whose compensation and job security are tied to their level of skill in stock selection. Instead, managements regularly interact with sell-side analysts who focus excessively on quarterly earnings. Managements have "learned" that reporting quarterly EPS below analysts' expected EPS, even if by a penny or so, invariably hurts the firm's stock price, at least for a time. It is no surprise then that managements and boards have developed a short-term-earnings point of view about valuation.

In direct contrast, mainstream finance offers the theoretically sound valuation decision rule: invest in all projects expected to produce a positive net present value. If a project achieves a return-on-investment (ROI) in excess of the cost of capital, then incremental wealth has been created. This long-term view assumes the market will "see through" any quarterly performance shortfalls that may be the unavoidable near-term cost of achieving wealth-creating ROIs.

One would expect that CFOs would be eager to educate CEOs and board members about the pitfalls of using a wealth creation compass tied to quarterly earnings to guide resource allocation decisions, but apparently they are not (Jensen and Fuller, 2002). For the most part, CFOs employ the same extreme focus on quarterly results as do sell-side analysts. There is some evidence that this is changing, with increased attention given to shareholder value related issues (McKinsey, 2007).

Survey research on CFOs by Graham, Harvey, and Rajgopal (2006) shows that CFOs regard meeting or exceeding quarterly EPS expectations as important to board members. Moreover, CFOs believe that multiple failures to meet short-term earnings targets would hurt their career prospects. In addition, the survey revealed that CFOs strongly agree that failure to meet quarterly expectations causes stock price declines and uncertainty about the firm's future prospects. The following quote succinctly summarizes the negative implications for value creation of some of the survey results:

[Eighty] percent of survey participants would decrease discretionary spending (e.g., R\&D, advertising, maintenance) to meet an earnings target, even though many CFOs acknowledge that suboptimal maintenance and other spending can be value destroying. More than half of the CFOs (55.3\%) said they would delay starting a new project to meet an earnings target, even if such a delay entailed a sacrifice in value. This evidence is interesting because CFOs appear to be willing to burn "real" cash flows for the sake of reporting desired accounting numbers (Graham et al., 2006).

\section{Intellectual Activism}

The key to achieving a better balance between shortterm operating results and long-term investments is greater activism by equity owners. In particular, they need to demand from boards of directors that an explicitly stated valuation model be committed to and described in the annual report, including its application to the firm's business units. The complete package has 
already been proposed as a Shareholder Value Review (Madden, 2007).

A successful proxy vote would manifestly demonstrate that the firm's owners believe that benefits from a Shareholder Value Review will exceed costs. This would overcome objections by management on grounds of "too costly" and "not needed."

The most critical reason for facilitating such a radical change seems obvious once it is pointed out. The survey researchers note, "Lacking a sense of history, analysts are prone to overreacting when the company misses an earnings target or when a new kink appears in the earnings path" (Graham et al., 2006).

Insightful business histories, i.e., long-term track records of key performance variables, are a needed guidepost for not only security analysts, but also managements and boards. The components of such track record displays would constitute a common wealth-creation template and language for promoting a now missing substantive dialogue between firms and the capital markets. Such wealth creation dialogue is necessary as an antidote to simplistic dialogue focused on a single earnings number. This more useful dialogue would address the complex managerial tasks involved with achieving both satisfactory near-term operating cash flows and securing long-term competitive advantage.

The important discounted cash flow valuation approach of Miller and Modigliani (1961) defines a firm's current market value, or wealth, as the present value (using the firm's cost of capital) of the future expected stream of net cash receipts. For a specific economic asset base, expected net cash receipts (operating cash flows less cash outlays for reinvestment) can be calculated from a forecast of the competitive life-cycle pattern of future economic returns and reinvestment rates.

The reinvestment rate reflects the annual growth rate in a firm's economic assets. The amount reinvested is used to replace fully-depreciated assets and add new capacity. Reinvestment is needed for both tangible assets and intangible assets; i.e., the same economic assets used in computing the economic return.

Figure 1 is a graphic representation of a firm's stylized history, showing transitions to different life-cycle stages. At any point in time, a firm's market value depends on the future pattern of the four numbered variables in this figure.

Importantly, a firm's up-to-date track record, comprised of these four variables, shows which life-cycle stage any firm is in. This alone helps to identify the key issues to consider in maximizing shareholder value.

In the life-cycle framework, one can observe the effects of Joseph Schumpeter's (1942) creative destruction at work - “... [the] kind of competition which counts ... competition from the new commodity, the new technology, the new source of supply, the new type of organizations ... competition which commands a deci- sive cost or quality advantage and which strikes not at the margins of the profits and the outputs of the existing firms but at their foundations and their very lives."

Frequently, the radical competition that Schumpeter alludes to comes from High Innovation stage firms. These firms have successfully developed a business that meets the fundamental criterion of wealth creation, namely economic returns (cash-based ROIs), well in excess of the cost of capital. Particularly successful firms exhibit high reinvestment rates in response to high demand for their products or services, and this creates additional wealth.

Firms next enter the Competitive Fade stage (Wiggins and Ruefli, 2005). Attracted by sizable wealth creation opportunities, competitors attempt to duplicate and improve upon the innovative product/service. Due to competitive pressure, firms' economic returns fade towards the cost of capital and reinvestment rates fade to lower levels (Fama and French, 2000). Maximizing shareholder value at any stage of the life-cycle revolves around critical decisions having the potential for producing more favorable long-term fade rates.

Next is the Mature life-cycle stage. Due to past successes, management typically is lulled into a businessas-usual complacency at the very time when top priority should be given to elevating economic returns above the cost of capital.

Lack of innovation, coupled with company-wide bureaucratic inefficiencies, usually accompanies a transition to the Failing Business Model stage. At this stage, purging business-as-usual practices and/or down-sizing are invariably required if the firm is to recover and avoid bankruptcy.

The premise that competition drives above-average profitability towards the average is not an abstract argument. It has been an observed phenomenon for a long time. And it is the root cause for past stock market winners to seldom keep their top-of-the-ladder position for long (Chan, Karceski, and Lakonishok, 2003).

In his Principles of Political Economy (a popular economics textbook of the mid-1800s), John Stuart Mill describes how capital moves (in accord with the invisible hand of Adam Smith) in response to "expectations of profit" so that "a sort of balance is restored" (Mill, 2004). The point is that skill and competition are core principles that ultimately determine long-term profitability.

\section{Conceptually Sound Valuation Principles}

An insightful use of these principles is contained in a speech made by Dwight Rose on December 27, $1928 .{ }^{1}$

${ }^{1}$ Rose's speech, "Common Stocks at the Current Price Level," was presented at the year-end 1928 joint annual meeting of the American Statistical Association and the American Economic Association. It was printed as a pamphlet and included in Rose (1928). 


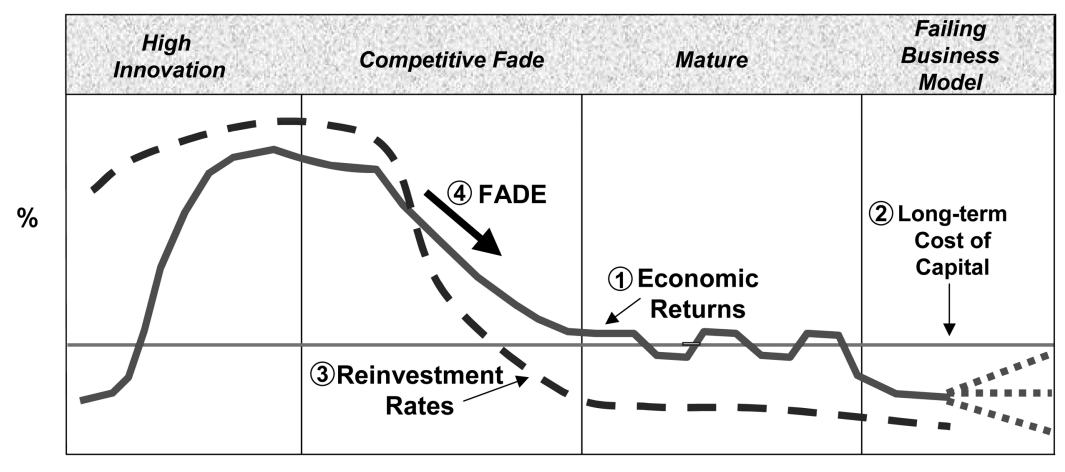

Contrary to the highly regarded economist Irving Fisher, who announced just before the beginning of the stock market crash of 1929 that "stock prices have reached what looks like a permanently high plateau," Rose, a portfolio manager who had done considerable research on trends in corporate performance over time, reached the following conclusion:

[D]o these changed conditions necessarily mean that the average corporation is going to show larger earnings on its capital? ... Is it not more likely that the principal beneficiary from all these influences will be the consumer rather than the producer or the investor? The average efficiency of business has increased. Those that do not keep up with the times must fall by the wayside in competition; those that are ahead of the times will show a correspondingly greater progress; but the average company will do little better than the average company has done in the past. In the last analysis we have a competition of capital seeking investment in any enterprise offering more than the average return, and more capital will continue to pour into such enterprises until the return of the average concern is on a basis commensurate with that in other fields.

But the fact that industry is growing and earnings increasing does not necessarily mean large profits to the common stock investor if all of these favorable factors have been discounted in an inflated market price (Rose, 1928).

To summarize, management and boards can gain useful experience with the life-cycle valuation model by focusing on the key valuation variables displayed in lifecycle track records. As a practical matter, the key variables of Figure 1 lead to the following basic rules for maximizing shareholder value:

1. Avoid investments in businesses likely to earn economic returns below the cost of capital.

\section{Figure 2. Life-Cycle Valuation Model}

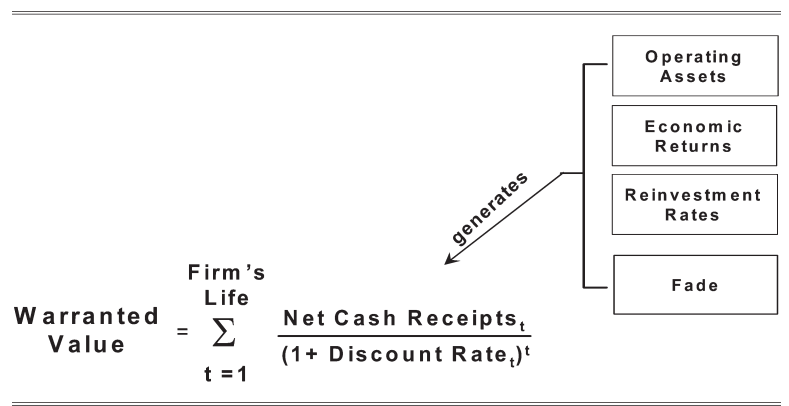

2. Reinvest in businesses likely to earn economic returns above the cost of capital.

3. Develop strategies that can realistically produce favorable future fade rates.

The big advantage of life-cycle track records is in communicating clearly how long-term levels and changes in stock prices link to managements' degree of success in executing the above rules. This is especially important because, without such easily understood empirical evidence, managements and boards are likely to default to the quarterly earnings model as the perceived fundamental driver of stock prices.

All conceptually sound valuation models incorporate some form of the four fundamental life-cycle variables: 1) economic returns, 2) reinvestment rates, 3) competitive fade, and 4) cost of capital (investors' discount rate). Figure 2 illustrates the role of these variables in generating net cash receipts which are discounted to a present value; i.e., a warranted value contingent upon the forecasted variables.

Figure 3 is a 1950 to 2006 track record for Eastman Kodak that reflects the variables of the life-cycle valuation model. 
Figure 3. Eastman Kodak

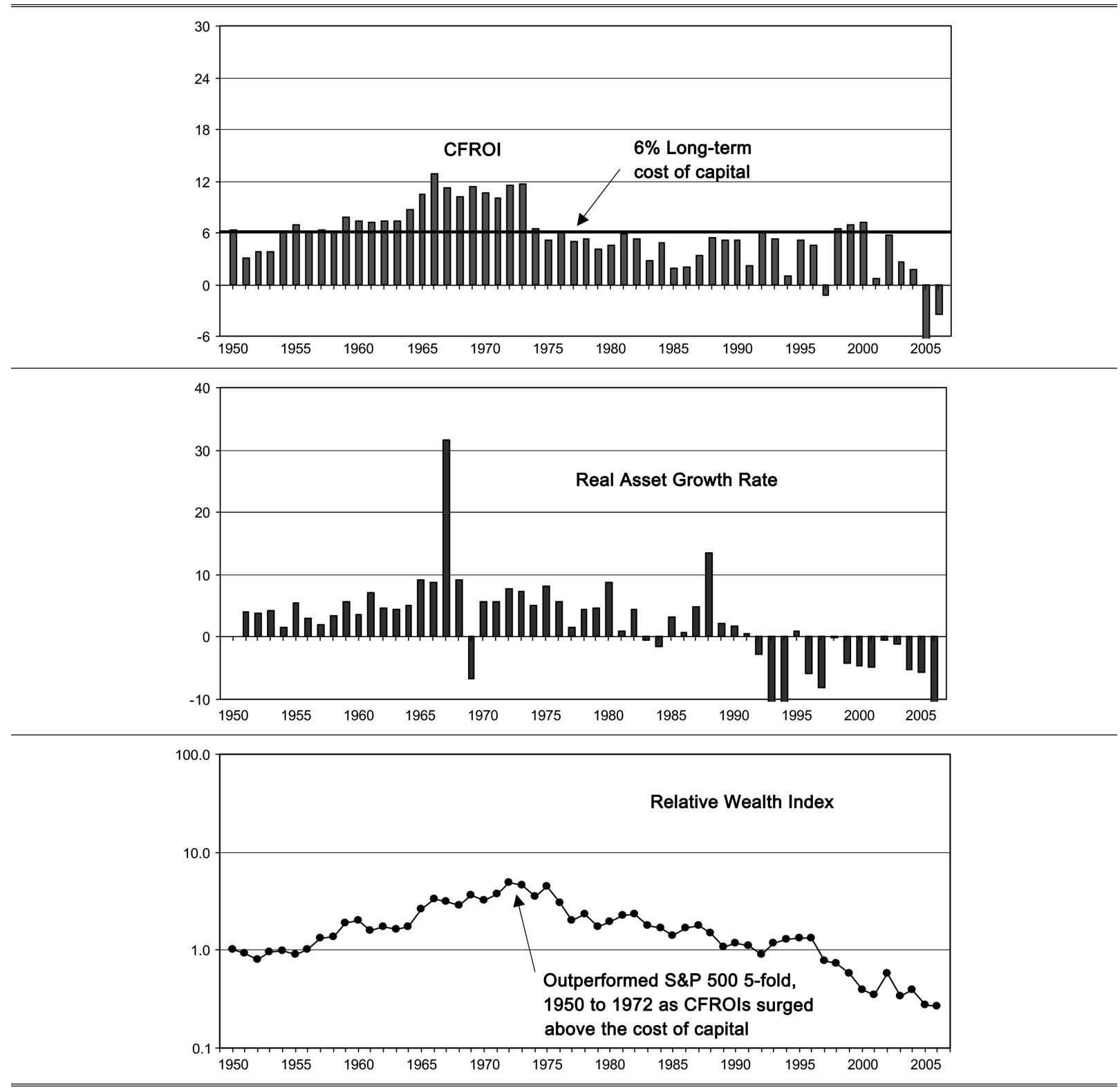

Source: Credit Suisse HOLT's ValueSearch ${ }^{\mathrm{TM}}$ database.

\section{Life-Cycle Chart}

The Eastman Kodak example illustrates a way of describing the life-cycle valuation model that should be informative to managements and boards. Certainly, better learning tools are needed to move corporate executives away from their extreme focus on quarterly earnings as the ultimate driver of shareholder value.

The life-cycle chart in Figure 3 is comprised of three panels. The top panel shows real (inflation adjusted) economic returns, estimated as a cash-flow-return-on-investment, or CFROI (Madden, 1999); including a benchmark, long-term corporate average CFROI of $6 \%$ real to approximate the cost of capital. ${ }^{2}$ The middle panel shows real asset growth rates. The bottom panel shows a cumulative index reflecting annual changes in the yearly excess (positive or negative) of the total shareholder return (dividends plus price appreciation) on the company's stock

${ }^{2}$ For the period 1960 to 1996, aggregate US industrial CFROIs approximated $6 \%$ real, and a "market-derived" real discount rate (cost of capital) also averaged approximately 6\% real (Madden, 1999). For the non-financial sector, 1950 to 1996, Fama and French (1999) estimated the real cost of capital at $5.95 \%$ and the return on corporate assets, unadjusted for inflation, at $7.38 \%$. 
relative to the S\&P 500. Positive share performance versus the $\mathrm{S} \& \mathrm{P} 500$ is depicted by rising trends in the relative wealth index, and negative performance by falling trends.

A firm's unique, up-to-date life-cycle reflects the interplay of skill and competition as recorded in the longterm fade patterns for economic returns and reinvestment rates. A firm's strategy (and the adaptability of that strategy over time) tends to be the key determinant of fade. The hallmark of an underperforming strategy is a firm's inability to consistently earn greater-than-cost-of-capital economic returns.

Ideally, management within a business unit should recognize at an early stage when their skill set is illsuited to secure competitive advantage in the future and they should redirect resources to more promising areas. A common situation is when current management "made its mark" operating a particular business (e.g., Eastman Kodak's film business) and slips into assuming the future will mirror the past. But conditions can radically change (e.g., new competitors or game-changing shifts in technology and customer needs such as the transition to digital photography).

Although difficult to accomplish, early recognition of upcoming competitive shortfalls or outright obsolescence can give needed time for experimentation without being under the crush of serious cash flow problems (Christensen and Raynor, 2003). Late recognition invariably results in the need for large-scale purging of business-as-usual, which is reflected in large negative asset growth rates (middle panel of the chart).

Long-term competitive advantage is simple to describe, but exceptionally difficult to achieve. The firm provides high value to customers using resources in a highly efficient manner that is difficult for competitors to duplicate. Economic returns are substantially in excess of the cost of capital and are sustained; i.e., do not rapidly fade downward over time. A firm can succeed in a highly specialized niche business, achieving high economic returns, but lack substantial reinvestment opportunities. Alternatively, far greater wealth is created when sustained high returns are coupled with high reinvestment rates.

In the early 1950s, as shown in the top panel of Figure 3, Eastman Kodak achieved economic returns (CFROIs) at or below the $6 \%$ real cost of capital. During the next 10 to 15 years CFROIs surged to $10-12 \%$ as Kodak profited from its dominance in film and cameras. Investors did not anticipate this upward fade in CFROIs and, as this improved performance was recognized, the stock substantially outperformed the general market (see bottom panel of Figure 3).

Since the mid-1970s, Kodak has greatly underperformed the market. A relentless stream of employee layoffs proved ineffective because management had failed to develop a viable, long-term strategy (Swasy, 1997).
Management and the board made a series of incremental "fixes" to address declining profitability.

Not only was there substantial competition from Fuji and others in consumer film, but Kodak's eventual participation in the technology shift to the digital age generated meager profits. In almost every year since 1985, the firm has recorded substantial restructuring charges (included in CFROI calculations). Since 1990, as shown in the middle panel of Figure 3, huge negative asset growth rates reflect asset impairments and divestitures as the firm belatedly changed its strategy. The life-cycle story of Kodak is still unfolding.

The main message of this example is that value-relevant track records, such as Figure 3, are useful in identifying core business problems at an early stage and promoting constructive skepticism about management's current strategy.

\section{V.What Works Best?}

If institutional money managers were to succeed in pressuring boards to adopt and implement a valuation model for guiding their decisions, publicly traded firms, of necessity, would start experimenting with track records. Then, the following question would move to center stage: What works best, in the eyes of managements and boards, to connect corporate performance to stock prices?

There would also be competition at the corporate level among alternative valuation products; i.e., among valuation models and the related routines for calculating input variables. Two criteria would most likely determine consumer choice:

1. The extent to which a favorable accuracy/simplicity tradeoff exists such that the benefits from more accurate calculations of track record variables clearly exceed the costs of added complexity.

2. The extent to which competing models promote substantive dialogue both within and outside the firm. The usefulness of such dialogue depends on a model's power to provide insights into key valuation issues, to facilitate plausibility judgments about forecasted business unit performance, and to promote improved ways of handling tough accounting/measurement issues and allocating capital.

Successful intellectual activism by shareholders would strip away the fuzzy platitudes about shareholder value so prevalent in today's annual reports. Instead, managements and boards would be compelled to publicly defend their key decisions within the context of value-relevant, long-term track records.

Perhaps some firms would initially attempt to build relevant track records by merely repackaging their existing performance metrics. The most popular performance 
metrics are growth in earnings per share and various measures of return on owners' capital such as return-onnet-assets or RONA (calculated as net income plus interest divided by net assets).

Knowledgeable investors, however, would then be on solid ground in criticizing corporate executives. Growth in earnings per share is a faulty wealth creation compass. The principal problem is that myriad short-term actions can boost reported earnings, but be counterproductive to the development of viable business processes that lead to long-term value creation.

A track record comprised solely of RONAs is incomplete because it lacks both the benchmark cost of capital and the magnitude of reinvestment, both of which are critical in determining the present value of the net cash receipt stream.

It is likely firms would either begin with some form of a life-cycle framework or eventually migrate there. It seems implausible that the academically popular residual income model would be used (Ohlson, 1995; and Feltham and Ohlson, 1995, 1996). This version of residual income employs an unadjusted earnings/book measure of ROI which is ill-suited as a proxy for economic returns. To its credit, the EVA version of residual income employs an adjusted RONA that strives to reflect underlying economic returns (Stewart, 1991).

\section{Economic Returns and Accounting Returns}

The biggest challenge in constructing life-cycle track records is the accuracy/simplicity tradeoff in estimating an economic return. The beginning point is to define an economic return.

Consider a completed investment project. There is a net cash receipt for each time period over the project's life, with earlier periods typically having negative net cash receipts due to high investment outlays. The economic return for the project is the internal rate of return, or return on investment (ROI) for the project, independent of accounting treatments; i.e., on a cash-out and cash-in basis.

If the net cash receipts for the completed project are unadjusted for changes in the purchasing power of the monetary unit, the measure is a nominal economic return. If all receipts are expressed in units of equivalent purchasing power, the measure is a real (inflation adjusted) economic return.

Competition operates through incremental or marginal investments. Capital is attracted to opportunities offering the prospect of achieving ROIs on new investments that exceed the cost of capital. And capital is withheld or withdrawn if the likelihood is that new investments will fail to earn the cost of capital. It is this process that is represented stylistically in Figure 1, Firms' Competitive Life-Cycle. Therefore, economic returns, not accounting returns, are plotted over time in Figure 1 to reinforce the point that the fundamental driving force of competition is expectations of achieved returns on incremental investments. With this perspective, one becomes much more careful in dealing with accounting ROIs.

A firm is an aggregation of ongoing projects. A crosssectional measure of accounting ROI derived from balance sheets and income statements represents an average ROI being achieved from the firm's portfolio of projects. Are those accounting-based, average ROIs useful approximations of the underlying average economic returns being achieved (Brief, 1986; Salmi and Martikainen, 1994; and Salmi, Nikkinen, and Sahlstrom, 2005)?

Welcome to the world of accounting adjustments that are needed to better reflect business economics. For example, consider a pharmaceutical company which expenses its R\&D outlays. At a minimum, capitalization of some portion of R\&D outlays (e.g., upon demonstration of commercial feasibility) is warranted. When a firm operates facilities that include fully depreciated assets, the standard RONA is misleadingly high because assets are understated. The list is a long one.

In this world, there rarely is a single, clear, right answer to get accounting data to mirror business economics. Such adjustments need to be grounded in economic reality, consistently applied to time series data, and transparent. Work in this area relies heavily on logical deductions and, to a lesser extent, on empirical tests of how well the revised return measure helps a valuation model in explaining levels and changes in historical stock prices. Salmi and Virtanen (1997) and Madden (1999) use simulations to analyze how profitability measures derived from as-reported financial statements correspond to known economic performance.

Interestingly, the vast majority of academic work on this topic is in accounting literature, with much less in finance literature. Perhaps the efficient-market logic of "no financial illusions" (Brealey, Myers, and Allen, 2006) has convinced many finance scholars that the market sees through accounting treatments and automatically develops the best estimate of economic returns. This view is of little help to those constructing track record displays or making decisions that allocate capital to business units.

\section{Competition for Best Practice}

Just as business processes need continual improvement, in a corporate environment of value-relevant track records there would be a continual learning process for management in working with data to better estimate underlying economic returns. As management and boards face public scrutiny of their Shareholder Value Reviews 
in their annual reports, they would put a high priority on the measurement of economic returns.

However, there are other pieces to the puzzle: cost of capital, reinvestment rates, and fade rates. The conventional CAPM/Beta calculation for cost of capital produces a wide variation of answers of questionable value (Fama and French, 1997).

An alternative is the implied cost of capital approach (Gebhardt, Lee, and Swaminathan, 2001; and Easton and Monahan, 2005) which estimates a forward-looking discount rate as the internal rate of return that equates the present value of forecasted net cash receipts to equity owners with current stock price. While this approach avoids estimating the future equity risk premium (Dimson, Marsh, and Staunton, 2003), one then must deal with estimating firms' future competitive fade rates.

As improvements are made to adjust accounting assets to "economic" assets, this automatically leads to more appropriate asset growth rates used to proxy reinvestment rates. The reinvestment rate should reflect organic (internally-generated) growth in investments, but acquisitions boost year-over-year asset growth rates. Moreover, acquisition goodwill, not being an operating asset, should be excluded from the asset base, yet management needs to be held accountable for the full cost of resources spent to make acquisitions.

Fade rates (trends over time) for both economic returns and reinvestment rates automatically improve as accounting distortions are minimized and asset bases more closely reflect actual business economics. But analyses of time series for economic returns or reinvestment rates face complications when the time period is long or comparisons are made to global competitors. Complications arise due to complex distortions of accounting RONAs from varying inflation rates.

Given the aforementioned big challenges, what is best practice?

The CFROI approach to those issues, developed over a long period of time, maintains a primary focus on accuracy for portfolio manager and security analyst use, and a secondary focus on strategic planning for corporations. The CFROI mindset is to display the four life-cycle variables and treat them as a total system for valuation purposes. ${ }^{3}$

${ }^{3}$ The CFROI valuation model originated in the 1970s at Callard Madden \& Associates and was subsequently advanced by HOLT Value Associates, which was acquired by Credit Suisse in 2002. Credit Suisse/HOLT currently delivers to money management firms a CFROI-oriented database/valuation model of 19,000 companies covering 59 countries.

The CFROI for industrial firms involves an internal rate-of-return calculation using four input variables: 1) gross assets marked up to current dollars (the same dollars as cash flows for a given year), 2) economic life for assets, 3) cash flow to all capital owners, and 4) the final release of current dollar non-depreciating assets. The explicit handling of these component parts helps to resolve problem areas and improve transparency (Madden, 1999, and Madden, 2005).
Keeping all of the life-cycle variables in "full view" (as done in the Eastman Kodak example), promotes both insights about key performance issues and continuous improvement in measurement techniques for all variables.

The EVA approach shares the same conceptual lifecycle basis as the CFROI approach. EVA offers simplicity by compressing the life-cycle variables into a single number. The simplicity of EVA-type metrics is useful in setting up incentives within the firm for promoting business decisions that benefit shareholder value.

Corporate customers for valuation models/track records would, in time, work out what is best practice to meet their needs. It is reasonable to expect to see future innovations that greatly improve the calculation of lifecycle variables, compared to today's versions of either CFROI or EVA.

A ripe area for innovation is in the development of performance measures for firms that are primarily comprised of intangibles, and how to link those new measures in a useful manner to a net cash receipt stream. Regardless of a firm's primary asset composition (intangible or tangible), managerial skill and competition interact over time to produce a net cash receipt stream - the true bottom line.

So far, managements have been loaded with a lot of new work in order to explain to shareholders how they attempt to fulfill their value maximization responsibility. That work will sharpen their analytical toolkit in at least three ways.

First, easy-to-understand empirical evidence would show the usefulness of the life-cycle lens. This would help them move away from a quarterly-earnings-centric framework. In this regard, analyses of life-cycle track records for a wide variety of firms, including competitors, customers, suppliers, and potential acquisition candidates, would be quite helpful.

Second, continued experience with value-relevant track records would tend to shift management's riskanalysis mindset and allow them to focus more on the numerator (cash flows) instead of the denominator (discount rate). A major lesson from studying track records is that significant long-term stock price gains/losses are invariably accompanied by plateau shifts in economic returns, which is the key driver of a firm's net cash receipt stream (Larrain and Yogo, 2007).

Risk can be configured as the distribution of net-cashreceipt outcomes, or scenarios. As higher probabilities are assigned to adverse scenarios, the expected (i.e., probability weighted) value of the distribution declines. This explicit handling of risk seems much preferred to simply boosting a discount rate to some level that "feels right" and discounting a single best-estimate scenario. This line of thinking sets the stage for more advanced, real-option, valuation methods (McDonald, 2006).

Third, management would likely make meaningful progress in connecting shareholder value to investments 
in intangibles and in devising ways to leverage intangibles. For example, for an R\&D intensive firm, what are the estimated achieved ROIs for major investments in different types of R\&D? This is important fundamental information that all too often is not addressed because it requires considerable work to unravel today's accounting data and make appropriate adjustments (Lev, 2004).

A recent empirical study (Bryant-Kutcher, Jones, and Widener, 2007) focused on how strategic human capital leads to competitive advantage. This study indicated that firms' market values were boosted by human capital that is both capable of creating operating efficiencies and difficult for competitors to imitate. The important point in this study is that instead of aggregating human resource outlays as "cost" items, these outlays warrant detailed analysis in terms of their potential to create wealth.

A final intangibles example deals with acquisition strategy. Morck and Yeung (2003) describe how a firm's intangible assets can be used in multiple businesses and locations simultaneously because intangibles are typically information-based. This suggests that acquisitions of businesses outside the firm's existing industry focus could be wealth creating when the acquiring firm has significant intangible assets that can be effectively leveraged in the new industry. Their empirical work strongly supported this type of strategic, intangibles-based thinking.

\section{Intangibles}

The beginning of a new, single global accounting system is taking shape as the Financial Accounting Standards Board (FASB) jointly works with the International Accounting Standards Board (IASB). The basic design process, i.e., how the accounting rule-makers think, is evident in a July 26, 2006 FASB report: Preliminary Views Conceptual Framework for Financial Reporting: Objective of Financial Reporting and Qualitative Characteristics of Decision-Useful Financial Reporting Information.

A legitimate criticism of the rule-makers' approach, as explained in that report, is that it abstracts (Madden, 1991) from the activities of the major users of accounting data, namely, managements and investors. The rulemakers strive to design a logically tight system of rules that should satisfy users. Future solicitation of comments from users on proposed new rules would presumably provide adequate user feedback. How useful, however, is feedback on intangibles from people who, in general, are not meaningfully engaged in working on the problem? ${ }^{4}$

\footnotetext{
${ }^{4}$ The Performance Measurement Association (PMA), http://www. performanceportal.org, is an academic-practitioner association involved with innovative projects about performance measurement and management, including intangibles. Also, Mourtisen, Bukh, and Marr (2005) provide a European perspective on the voluntary reporting of intellectual capital.
}

Although it lacks the specificity of the life-cycle valuation model, the Conceptual Framework report embraces the basic principles about net cash receipts and economic returns:

To help achieve its objective, financial reporting should provide information to help present and potential investors and creditors and others to assess the amounts, timing, and uncertainty of the entity's future cash inflows and outflows ...

An entity's financial performance provides information about the return it has produced on the economic resources it controls. In the long run, an entity must produce a positive return on its economic resources if it is to generate net cash inflows and thus provide a return to its investors and creditors. The variability of that return is also important, especially in assessing the uncertainty of future cash flows, as is information about the components of that return. Investors and creditors usually find information about an entity's past financial performance helpful in predicting the entity's future returns on its resources, which will be its future financial performance (FASB, 2006).

Configuring accounting data to more accurately reflect economic returns is at the heart of the accuracy/simplicity tradeoff in constructing track records. Consider a firm making substantial cash outflows for intangibles in early years that contribute to substantial cash inflows in later years. The expensing of intangibles results in accounting earnings being understated in the early years and overstated in the later years. The root cause of the trouble is a mismatch between revenues and expenses.

This viewpoint argues for an open mind on capitalizing and amortizing outlays as a way to alleviate the mismatch problem. Researchers have produced a useful body of empirical research demonstrating the value-relevance of intangibles (e.g., Lev, 2001; Hand and Lev, 2003; and Lev, 2004).

For the rule-makers, the critical issue is deciding which intangibles are both important enough for inclusion in financial reports and can meet the requirement of faithful representation of real-world economic phenomena. In other words, the challenge is to move from "hard" numbers to "soft" numbers and effectively deal with the tradeoff of objectivity versus relevance (Upton, 2001).

A useful angle on this challenge puts intangibles into the context of the life-cycle model, including its fade component. We need an open mind for capitalizing and amortizing intangibles, and an open mind about the valuation needs and ingenuity of both managements and investors.

Intangibles that are value-relevant, but difficult to quantify in terms of capitalization and amortization, include outlays for brand names, employee training and 
retention, unique and difficult-to-duplicate organizational processes, research and development, and much more. $^{5}$

As for brand advertising (Kallapur and Kwan, 2004; and Goldfarb, Lu, and Moorthy, 2006), an investor would want to know, at a minimum, how much is spent to support various brands and some objective measures of brand strength. Would it be useful to capitalize and amortize outlays for building/maintaining brand names? Probably not. Knowledgeable investors would likely incorporate a firm's brand strength in their forecasts of long-term fade rates. Note that the inherent "soft" nature of brands fits the qualitative judgment intrinsic to fade rate forecasts. This approach avoids putting a highly questionable value for brands on the balance sheet.

On the other hand, for R\&D intensive firms, knowledgeable investors would most likely prefer managements, as part of constructing track records, to capitalize and amortize R\&D (Lev, Sarath, and Sougiannis, 2005; and Danielson and Press, 2005) and explain their methodology (Healy, Myers, and Howe, 2002). In this case, the failure to capitalize and amortize creates serious distortions in economic returns and reinvestment rates. Many institutional investors are already making these types of adjustments and would benefit from knowing managements' views (Wyatt, 2005).

Particularly useful guidance for the accounting rulemakers could come from corporations' published Shareholder Value Reviews. Investors would thereby be engaged in a substantive discussion about tough measurement issues such as brand names and R\&D. Many important technical issues are seen in a different light when put into the context of value-relevant track records. For example, one often encounters the notion that the logic for fair value (mark-to-market) accounting treatment is unarguable (CFA Institute, 2005; and Miller and Bahnson, 2007).

I disagree with the position that historical cost data is unnecessary. One can adopt the life-cycle valuation framework and argue that the usefulness of an accounting concept becomes apparent in working with the data in a purposeful manner. For the purpose of estimating economic returns, it is imperative to have the original (historical) cost of assets. Knowledge of past economic

\footnotetext{
${ }^{5}$ Recent research by Hewitt Associates has linked human capital investments to subsequent changes in financial performance (measured as CFROI change) based on a proprietary database of 20 million employees in 1,000 large companies. A metric was developed that measures the effectiveness of a firm's human resource policies in the attraction and retention of pivotal (higher pay grade) employees, and it appears to have predictive value for future financial performance. This research is important because it shows that investments in human capital can be quantified in terms of a financial return on investment. See http://www. evidence-basedmanagement.com/guests/ubelhart _jan07.html.
}

returns guides a judgment of managerial skill, which helps in forecasting future economic returns.

\section{Conclusion}

In their self-interest, shareholders in general, and institutional money managers in particular, should pressure boards of directors and managements to periodically produce a Shareholder Value Review. It should display value-relevant, long-term track records for the firm and its major business units. These track records should be the centerpiece of a substantive discussion about maximizing shareholder value. Potential benefits include:

1. Expedited learning by managements and boards about how firms' economic performance connects to shareholder value;

2. Expanded role for CFOs and their staffs to provide the most useful track record displays and to organize related supplemental disclosures providing useful information (Christensen and Demski, 2002) about intangibles and other important issues;

3. A more productive dialogue among the board, management, and investors, leading to quicker and better decisions for maximizing shareholder value;

4. Greater willingness by management to commit to value-creating projects that may reduce nearterm earnings and to explain their decisions to shareholders;

5. More attention by accounting rule-makers to the experiences of primary users of accounting data in dealing with measurement problems critical to wealth creation.

At least two obstacles stand in the way of achieving these benefits. First, is inertia. The ideal situation is for some firms to voluntarily produce Shareholder Value Reviews that demonstrate the practicality of the concept. Nevertheless, widespread adoption would most probably require major proxy campaigns orchestrated by institutional shareholders.

The second obstacle would be CEOs who want track records to be constructed, not to mirror the reality of business economics, but to simply puff up their reported life-cycle performance. To address this problem, shareholders should be forceful in demanding that the displayed life-cycle components have sufficient detail that outsiders could reproduce the results. For example, business unit disclosure should include the standard accounting data and adjustments made to calculate an economic return.

Perhaps $R \& D$ expense was capitalized with a five year life. Some investors might want to use a different 
adjustment for R\&D. And by having a transparent process, investors could calculate their own versions of an economic return.

Finally, one would expect investors to be suspicious of a firm that chose an adjustment whose effect was to boost its economic returns if that adjustment was clearly an outlier compared to other firms in the same industry.

\section{References}

Bebchuk, L.A., 2007, "The Myth of the Shareholder Franchise," Virginia Law Review 93 (No. 3, May), 675-732.

Bebchuk, L. and J. Fried, 2004, Pay Without Performance, Cambridge, MA, Harvard University Press.

Brealey, R.A., S.C. Myers, and F. Allen, 2006, Principles of Corporate Finance, $8^{\text {th }}$ Edition, New York, NY, McGraw-Hill Irwin.

Brief, R.P., 1986, Estimating the Economic Rate of Return From Accounting Data, New York, NY, Garland Publishing.

Bryant-Kutcher, D., A. Jones, and S.K. Widener, 2007, "Market Valuation of Intangible Resources: The Use of Strategic Human Capital," Advances in Management Accounting, Forthcoming.

CFA Institute, 2005, A Comprehensive Business Reporting Model: Financial Reporting for Investors.

Chan, L.K.C., J. Karceski, and J. Lakonishok, 2003, "The Level and Persistence of Growth Rates," Journal of Finance 58 (No. 2, April), 643-684.

Charron, D.C., 2007, "Stockholders and Stakeholders: The Battle for Control of the Corporation," Cato Journal 27 (No. 1, Winter), 1-23.

Christensen, C.M. and M.E. Raynor, 2003, The Innovator's Solution, Boston, MA, Harvard Business School Publishing.

Christensen, J. and J.S. Demski, 2002, Accounting Theory: An Information Content Perspective, New York, NY, McGraw-Hill/ Irwin.

Corrado, C., J. Haltiwanger, and D. Sichel, 2005, Measuring Capital in the New Economy, Chicago, IL, University of Chicago Press.

Danielson, M.G. and E. Press, 2005, "When Does R\&D Expense Distort Profitability Estimates?" Journal of Applied Finance 15 (No. 2, Fall/Winter) 76-92.

Dimson, E., P. Marsh, and M. Staunton, 2003, "Global Evidence on the Equity Risk Premium," Journal of Applied Corporate Finance 15 (No. 4, Summer), 8-19.

Easton, P.D. and S.J. Monahan, 2005, "An Evaluation of AccountingBased Measures of Expected Returns," Accounting Review 80 (No. 2, April), 501-538.

Fama, E.F. and K.R. French, 1997, "Industry Costs of Equity," Journal of Financial Economics 43 (No. 2, February), 153-193.

Fama, E.F. and K.R. French, 1999, "The Corporate Cost of Capital and the Return on Corporate Investment," Journal of Finance 54 (No. 6, December), 1939-1967.
Also, consulting firms (especially auditing firms) would likely play a major role in helping firms produce value-relevant track records. Having their names (reputations) attached to Shareholder Value Review data would be an added motivation to do quality work; i.e., for producing track records that reflect the reality of business economics.
Fama, E.F. and K.R. French, 2000, "Forecasting Profitability and Earnings," Journal of Business 73 (No. 2, April), 161-175.

Feltham, G. and J. Ohlson, 1995, "Valuation and Clean Surplus Accounting for Operating and Financial Activities," Contemporary Accounting Research 11 (No. 2, Spring), 689-731.

Feltham, G. and J. Ohlson, 1996, "Uncertainty Resolution and the Theory of Depreciation Measurement," Journal of Accounting Research 34 (No. 2, Autumn), 209-234.

Financial Accounting Standards Board, 2006, Preliminary Views Conceptual Framework for Financial Reporting: Objectives of Financial Reporting and Qualitative Characteristics of Decision-Useful Financial Reporting Information, July 6 (No. 1260-001).

Gebhardt, W.R., C.M.C. Lee, and B. Swaminathan, 2001, "Toward an Implied Cost of Capital," Journal of Accounting Research 39 (No. 1, June), 135-176

Goldfarb, A., Q. Lu, and S. Moorthy, 2007, "Measuring Brand Value in an Equilibrium Framework," (August), Social Science Research Network, http://ssrn.com/abstract=917364.

Graham, J.R., C.R. Harvey, and S. Rajgopal, 2006, "Value Destruction and Financial Reporting Decisions," Financial Analysts Journal 62 (No. 6, November-December), 27-39.

Hand, J. and B. Lev, 2003, Intangible Assets: Values, Measures, and Risks, London, England, Oxford University Press.

Healy, P.M., S.C. Myers, and C.D. Howe, 2002, "R\&D Accounting and the Tradeoff Between Relevance and Objectivity," Journal of Accounting Research 40 (No. 3, June), 677-710.

Jensen, M.C. and J. Fuller, 2002, "Just Say No to Wall Street," Journal of Applied Corporate Finance 14 (No. 4, Winter), 41-46.

Kallapur, S. and S.Y.S. Kwan, 2004, "The Value Relevance and Reliability of Brand Assets Recognized by U.K. Firms," Accounting Review 79 (No. 1, January), 151-172.

Larrain, B. and M. Yogo, 2007, "Does Firm Value Move Too Much to be Justified by Subsequent Changes in Cash Flow?" NBER Working Paper 12847.

Lev, B., 2001, Intangibles: Management, Measurement, and Reporting, Washington, D.C., Brookings Institution Press.

Lev, B., 2004, "Sharpening the Intangibles Edge," Harvard Business Review (June), 109-116. 
Lev, B., B. Sarath, and T. Sougiannis, 2005, "R\&D Reporting Biases and Their Consequences," Contemporary Accounting Research 22 (No. 4, Winter), 977-1026.

Madden, B.J., 1991, "A Transactional Approach to Economic Research," Journal of Socio-Economics 20 (No. 1, April), 5771.

Madden, B.J., 1999, CFROI Valuation - A Total System Approach to Valuing the Firm, Oxford, UK, Butterworth-Heinemann.

Madden, B.J., 2005, Maximizing Shareholder Value and the Greater Good, Naperville, IL, LearningWhatWorks.

Madden, B.J., 2007, "For Better Corporate Governance, the Shareholder Value Review," Journal of Applied Corporate Finance 19 (No. 1, Winter), 102-114.

McDonald, R., 2006, "The Role of Real Options in Capital Budgeting: Theory and Practice," Journal of Applied Corporate Finance 18 (No. 2, Spring), 28-39.

McKinsey Global Survey, 2007, "The State of the Corporate Board," McKinsey Quarterly (June).

Mill, J.S., 2004, Principles of Political Economy, Amherst, NY, Promethus Books.

Miller, M.H. and F. Modigliani, 1961, "Dividend Policy, Growth, and the Valuation of Shares," Journal of Business 34 (No. 4, October), 411-433.

Miller, P.B.W. and P.R. Bahnson, 2007, "The Top 10 Reasons to Fix the FASB's Conceptual Framework," Strategic Finance (July), 43-49.

Morck, R. and B. Yeung, 2003, "Why Firms Diversify: Internalization vs Agency Behaviour," in J. Hand and B. Lev, Eds., Intangible Assets: Values, Measures, and Risks, London, England, Oxford University Press.

Mourtisen, J., Bukh, P.N., and B. Marr, 2005, "A Reporting Perspective on Intellectual Capital," in B. Marr, Ed., Perspectives on Intellectual Capital, Oxford, UK, Elsevier ButterworthHeinemann.
Ohlson, J., 1995, "Earnings, Book Values, and Dividends in Equity Valuation," Contemporary Accounting Research 11 (No. 2, Spring), 661-687.

Rappaport, A., 2005, "The Economics of Short-Term Performance Obsession," Financial Analysts Journal 61 (No. 3, May/June), 65-79.

Rose, D.C., 1928, A Scientific Approach to Investment Management, New York, NY, Harper \& Brothers Publishers.

Salmi, T. and T. Martikainen, 1994, "Review of the Theoretical and Empirical Basis of Financial Ratio Analysis," Finnish Journal of Business Economics 43 (No. 4), 426-448.

Salmi, T. and I. Virtanen, 1997, "Measuring the Long-Run Profitability of the Firm; A Simulation Evaluation of the Financial Statement Based IRR Estimation Methods," Acta Wasaensia, (No. 54).

Salmi, T., Nikkinen, J., and P. Sahlstrom, 2005, "The Review of the Theoretical and Empirical Basis of Financial Ratio Analysis Revisited,"World Wide Web publication URN:NBN:fi-fe20051937, University of Vaasa, Finland, http://lipas.uwasa.fi/ ts/wbfa/wbfa. htm.

Schumpeter, J.A., 1942, Capitalism, Socialism and Democracy, New York, NY, Harper \& Row.

Stewart, G.B., 1991, The Quest for Value, New York, NY, Harper Business.

Swasy, A., 1997, Changing Focus, New York, NY, Random House.

Trammell, S., 2004, "Black in the Box," CFA Magazine, (NovemberDecember), 26-29.

Upton, W.S., 2001, Special Report-Business and Financial Reporting, Challenges from the New Economy, FASB (No. 219-A).

Wiggins, R.R. and T.W. Ruefli, 2005, "Schumpeter's Ghost: Is Hypercompetition Making the Best of Times Shorter?" Strategic Management Journal 26 (No. 10, October), 887-911.

Wyatt, A., 2005, “Accounting Recognition of Intangible Assets: Theory and Evidence on Economic Determinants," Accounting Review 80 (No. 3, July), 967-1003. 